\title{
Profil Metabolit Darah Sapi Bali Jantan yang Diberikan Pakan Hasil Integrasi Rumput - Legume - Tanaman Pangan di Lahan Kering Pulau Timor
}

\section{Metabolic Blood Profile of Male Bali Cattle That at Gives Integration Feed Grass- Legume and Food Cropsin Dry Land Timor Island}

\section{Grace Maranatha $^{1) *}$, Sukawaty Fattah ${ }^{1)}$, Jacob Nulik ${ }^{2)}$, Ulrikus Romsen Lole ${ }^{1)}$, Yohanis Umbu Laiya Sobang ${ }^{1}$, Fredeicus Dedy Samba ${ }^{3)}$}

${ }^{1)}$ Fakultas Peternakan, Universitas Nusa Cendana, Kupang, NTT 85361 Indonesia

2) Balai Pengkajian Teknologi Pertanian Nusa Tenggara Timur, Naibonat Km.32, NTT Indonesia

3) Program Pascasarjana Universitas Nusa Cendana, Kupang, NTT 85361 Indonesia

\section{Article history \\ Received: Aug 01, 2020; \\ Accepted: Jul 26, 2021 \\ * Corresponding author: \\ E-mail: \\ gmar.timore2367@gmail.co $\mathrm{m}$ \\ DOI: \\ 10.46549/jipvet.v11i2.130

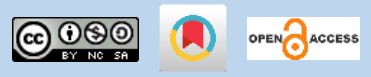

\begin{abstract}
This study aims to determine the effect of feeding the results of integration of superior grass-legume Clitoria tarnatea and food crops in fattening bali cattle at the farmer level on blood urea, glucose, and hemoglobin levels. This study used 8 male Bali cattle in the age range of $1-1.5$ years with a body weight of 101-134 $\mathrm{kg}$, with an average of $114.25 \mathrm{~kg}$ and a coefficient of variation of $6.12 \%$. The research method used is an experimental method using a double Latin Square Design (LSD) with 4 treatments and each treatment was tried on 2 cattle, while the replications were 4 time periods so that there were 32 experimental units. Treatment in this study; $\mathrm{P}_{1}$ : integrated feed of mulato grass + legumes + corn + rice beans + pumpkin, $\mathrm{P}_{2}$ : integrated feed of odot grass + legumes + corn + rice beans + pumpkin, $\mathrm{P}_{3}$ : integrated feed of Setaria grass + legume + corn + rice beans + pumpkin, $\mathrm{P}_{4}$ : integrated feed of Brachiaria grass + legumes + corn + rice beans + pumpkin. The data obtained were analyzed using analysis of variance ANOVA. The results showed that the treatment had no significant effect $P>0.05$ on the blood urea, glucose and hemoglobin levels of fattening male Bali cattle. The conclusion of this study was that the feed treatment did not have an effect between treatments on the blood metabolite profile which included urea, glucose and blood hemoglobin of fattening male bali cattle so that it could be used as an alternative feed for male bali cattle.
\end{abstract}

Keywords: Dry land; Food crops; Integration feed grass-legume; Male bali cattle; Metabolic blood

\section{Abstrak}

Penelitian ini bertujuan untuk mengetahui pengaruh pemberian pakan hasil integrasi rumput unggul-legume Clitoria tarnatea dan tanaman pangan pada sapi bali jantan penggemukan ditingkat peternak terhadap kadar urea, glukosa, dan hemoglobin darah. Penelitian ini menggunakan 8 ekor sapi Bali jantan bakalan pada kisaran umur 1 - 1,5 tahun dengan berat badan 101-134 kg, dengan rataan $114,25 \mathrm{~kg}$ dan koefisien variasi $6,12 \%$. Metode penelitian yang digunakan adalah metode percobaan menggunakan rancangan bujur sangkar latin ganda (RBSL) dengan 4 perlakuan dan masing-masing perlakuan dicoba pada 2 ekor ternak, sedangkan ulangan sebanyak 4 periode waktu sehingga terdapat 32 unit percobaan. Perlakuan dalam penelitian ini; $\mathrm{P}_{0}$ : pakan hasil integrasi rumput mulato + legum + jagung + kacang nasi + labu kuning, $\mathrm{P}_{1}$ : pakan hasil integrasi rumput odot + legum + jagung + kacang nasi + labu kuning, $\mathrm{P}_{2}$ : pakan hasil integrasi rumput Setaria + legume + jagung + kacang nasi + labu kuning, $\mathrm{P}_{3}$ : pakan hasil integrasi rumput Brachiaria + legum + jagung + kacang nasi + labu kuning. Data 
yang diperoleh dianalisis menggunakan analisis sidik ragam ANOVA. Hasil penelitian menunjukan bahwa perlakuan berpengaruh tidak nyata $\mathrm{P}>0,05$ terhadap kadar urea, glukosa dan hemoglobin darah sapi Bali jantan penggemukan. Kesimpulan dari penelitian ini adalah perlakuan pakan tidak memberikan pengaruh antar perlakuan terhadap profil metabolit darah yang meliputi urea, glukosa dan hemoglobin darah sapi bali jantan penggemukan sehingga dapat dijadikan pakan alternatif bagi sapi bali jantan.

Kata kunci: Integrasi pakan rumput-legume; Metabolit darah; Sapi bali jantan; Tanaman pangan

\section{PENDAHULUAN}

Produktivitas sapi bali jantan penggemukan di daerah lahan kering Pulau Timor masih tergolong rendah yang ditenggarai disebabkan oleh musim. Keadaan ini tidak saja memberikan dampak terhadap komoditi peternakan, melainkan memberikan dampak pula terhadap komoditi pertanian berupa tanaman pangan untuk memenuhi kebutuhan pokok masyarakat.

Pemanfaatan lahan pertanian yang kurang optimal oleh petani-peternak serta manajemen pemeliharaan ternak yang masih bertumpu pada budidaya tradisional menyebabkan pemberian pakan menjadi kurang optimal dan menjadi permasalah rendahnya produktivitas ternak sapi di NTT. Lahan pertanian hanya di fokuskan pada satu sub-sektor tanpa adanya perpaduan dengan sub-sektor lain sehingga hasil akhir dari proses tersebut hanya menghasilkan satu komoditi, adapun pemanfaatannya hanya sisa sampingan atau limbah berupa jerami dengan kualitas rendah yang diberikan pada ternak.

Melihat hal tersebut maka perlu adanya suatu langkah pembaruan untuk memanfaatkan lahan lebih optimal terutama pada daerah lahan kering dengan menggabungkan antara komoditi pertanian dan peternakansecara terpadu melalui integrasi tanaman pangan dan pakan ternak. Menurut Kariyasa (2005) model integrasi dapat membantu petani mengatasi permasalahan ketersediaan pakan, ditambahkan Nurhidayati et al., 2008) sistem pertanian terpadu adalah sistem yang menggabungkan antara usaha peternakan konvensional, budidaya perairan, hortikultura, agroindustri, dan segala aktivitas pertanian. Pembangunan berkelanjutan merupakan satu-satunya cara untuk meningkatkan pemanfaatan sumber daya secara rasional tanpa menghambat pertumbuhan ekonomi, sistem integrasi tanaman-ternak memegang peranan sangat penting sehingga tidak ada produk yang terbuang serta pemanfaatan lahan pertanian menjadi lebih optimal (Gupta et al., 2012).

Melihat urgensi dari beberapa hasil yang diperoleh peneliti terdahulu mengenai keunggulan dari integrasi pakan untuk meningkatkan ketersediaan pakan yang berkesinambungan melalui perpaduan tanaman dan ternak berbasis zero wasted untuk produktivitas ternak serta perkembagan ilmu mengenai integrasi tanaman dan ternak telah banyak dilakukan namun masih sebatas percobaan secara in vitro, sedangkan informasi mengenai pemberian pakan hasil integrasi secara in vivo masih sangat minim, maka pemberian pakan tersebut secara langsung pada ternak perlu diketahui dampaknya terhadap pertumbuhan dan kondisi fisiologis ternak, salah satu cara untuk mengetahui dampak pemberian pakan pada ternak yaitu dengan mengetahui gambaran metabolit darah ternak untuk mengevaluasi kualitas pakan yang diberikan pada ternak. Oleh karena itu penelitian ini bertujuan untuk mengetahui pengaruh pemberian pakan hasil integrasi rumput unggul - legume Clitoria tarnatea dan tanaman pangan pada sapi bali jantan penggemukan ditingkat peternak terhadap kadar glukosa, urea dan hemoglobin darah.

\section{METODE PENELITIAN}

\section{LOKASI DAN WAKTU}

Penelitian ini dilakukan di Desa Oeletsala, Kecamatan Taebenu, Kabupaten Kupang, NTT. selama 19 minggu, waktu ini terbagi dalam 4 periode, masing-masing periode terdiri atas 4 
minggu waktu pengambilan data dan 1 minggu waktu jeda sebelum memasuki periode selanjutnya dimana perlakuan bergulir pada ternak lainnya.

\section{MATERI PENELITIAN}

Ternak yang digunakan dalam penelitian ini adalah 8 ekor sapi bali jantan bakalan pada kisaran umur 1-1,5 tahun dengan kisaran berat badan 101-134 kg, dengan rataan 114,25 kg dan koefisien variasi $6,12 \%$. Kandang yang digunakan adalah kandang individu sebanyak 8 petak, dengan setiap petak berukuran $1,5 \times 2 \mathrm{~m}$ dilengkapi tempat pakan dan minum.Peralatan yang digunakan terdiri dari timbangan ternak merk sonic berkapasitas $1000 \mathrm{~kg}$ dengan kepekaan $0,5 \mathrm{~kg}$, timbangan pakan merk moris scale berkapasitas $100 \mathrm{~kg}$ dengan kepekaan 100 $\mathrm{g}$ dan timbangan untuk menimbang pakan konsentrat merk camry scale berkapasitas $5 \mathrm{~kg}$ dengan kepekaan $1 \mathrm{~g}$ serta alat bantu lainya untuk mengambil dan menganalisis parameter darah. Bahan pakan yang digunakan pada penelitian ini adalah pakan hasil integrasi dengan komposisi seperti pada perlakuan dan kandungan nutrisi dari pakan yang diberikan tersaji pada Tabel 1.

Tabel 1. Kandungan Nutrisi Pakan Perlakuan

\begin{tabular}{|c|c|c|c|c|c|c|c|c|c|}
\hline \multirow{2}{*}{ Perlakuan } & \multirow{2}{*}{$\%$ BK } & \multirow{2}{*}{$\begin{array}{c}\text { BO } \\
(\% \mathrm{BK})\end{array}$} & \multirow{2}{*}{$\begin{array}{c}\text { PK } \\
(\% \mathrm{BK})\end{array}$} & \multirow{2}{*}{$\begin{array}{c}\text { LK } \\
(\% \mathrm{BK})\end{array}$} & \multirow{2}{*}{$\begin{array}{c}\text { SK } \\
(\% \mathrm{BK})\end{array}$} & \multirow{2}{*}{$\begin{array}{c}\text { CHO } \\
(\% \text { BK })\end{array}$} & \multirow{2}{*}{$\begin{array}{c}\text { BETN } \\
(\% \text { BK })\end{array}$} & \multicolumn{2}{|c|}{ Energi } \\
\hline & & & & & & & & MJ/kg BK & Kkal/kg BK \\
\hline $\mathrm{P}_{0}$ & 36,24 & 81,24 & 18,94 & 6,52 & 24,81 & 55,78 & & 16,46 & $3.920,19$ \\
\hline $\mathrm{P}_{1}$ & 34,40 & 82,94 & 19,68 & 6,46 & 21,74 & 56,80 & 35,06 & 16,80 & $4.000,03$ \\
\hline $\mathrm{P}_{2}$ & 33,41 & 78,99 & 15,66 & 5,88 & 28,11 & 57,45 & 29,34 & 15,74 & $3.747,71$ \\
\hline $\mathrm{P}_{3}$ & 30,44 & 80,07 & 16,54 & 6,31 & 22,67 & 57,22 & 34,55 & 16,06 & $3.823,95$ \\
\hline
\end{tabular}

Ket : Hasil analisis laboratorium nutrisi ternak IPB 2019, sampel pakan di ambil setiap hari sebanyak 10\% dari jumlah pemberian pada ternak dan di komposit pada akhir penelitian untuk di analisis nilai nutrisinya,

\section{METOdE PENELITIAN}

Metode penelitian yang digunakan adalah metode percobaan, menggunakan Rancangan Bujur Sangkar Latin (RBSL) dengan 4 perlakuan dan 4 periode sebagai ulangan. Adapun perlakuan dalam penelitian ini adalah: $\mathrm{P}_{1}=$ pakan hasil integrasi rumput mulato + legume clitoria + jagung + kacang nasi + labu kuning (diberikan $10 \%$ dari BB ternak)

$\mathrm{P}_{2}=$ pakan hasil integrasi rumput gajah mini + legume clitoria + jagung + kacang nasi + labu kuning (diberikan 10\% dari BB ternak)

$\mathrm{P}_{3}=$ pakan hasil integrasi rumput Setaria spacelata ++ legume clitoria + jagung + kacang nasi + labu kuning (diberikan $10 \%$ dari BB ternak)

$\mathrm{P}_{4}=$ pakan hasil integrasi rumput Brachiaria decumbens + legume clitoria + jagung + kacang nasi + labu kuning (diberikan $10 \%$ dari BB ternak)

\section{PROSEDUR ANALISA PARAMETER YANG DITELITI:}

Parameter yang diamati meliputi kadar glukosa, urea dan hemoglobin darah sesuai petunjuk Laboratorium Patologi Klinik (2004). Sampel disentrifuge pada kecepatan $3.000 \mathrm{rpm}$ selama 10 menit, diambil plasma darah untuk dianalisis kandungan glukosa, urea dan total protain plasma.

a. Prosedur analisis glukosa plasma darah adalah siapkan 2 kuvet spektro, kuvet pertama dicampur plasma darah $10 \mu \mathrm{l}$ dan reagen warna $1 \mathrm{ml}$. Kuvet kedua campur reagen standar $10 \mu \mathrm{l}$, reagen warna $1 \mathrm{ml}$. Sampel yang telah disiapkan kemudian diinkubasi pada suhu $20{ }^{\circ} \mathrm{C}$ selama 20 menit. Setelah inkubasi, sampel dianalisis menggunakan Spectrofotometer $u v$ vis agilent carry 60 dengan panjang gelombang $546 \mathrm{~nm}$, yang telah tersambung dengan layar monitor. Baca abs. sampel dan abs. reagen standar dan dihitung sesuai rumus berikut :

(Abs. sampel/Abs. Standar) x $100 \mathrm{mg} / \mathrm{dl}$. 
b. Prosedur analisis urea plasma darah adalah siapkan 2 kuvet spektro, kuvet pertama dicampur plasma darah $10 \mu \mathrm{l}$ dan reagen warna $1 \mathrm{ml}$. Kuvet kedua dicampur reagen standar $10 \mu \mathrm{l}$, reagen warna $1 \mathrm{ml}$. Sampel yang telah disiapkan kemudian diinkubasi pada suhu 20 oC selama 5 hari. Setelah inkubasi, sampel dianalisis menggunakan Spectrofotometer Spectrofotometer uv vis agilent carry 60 dengan panjang gelombang $340 \mathrm{~nm}$, yang telah tersambung dengan layar monitor. Baca abs. sampel dan abs. reagen standar dan dihitung sesuai rumus berikut :

(Abs. sampel/Abs. Standar) x $50 \mathrm{mg} / \mathrm{dl}$.

c. Hemoglobin (HB)

Pemeriksaan HB darah menggunakan Hematology Analyser OL-2100 OneLab, dimana tabung yang berisi darah dimasukan ke tempat sampel pada Hematology Analyser kemudian tekan tombol count untuk menghitung nilai hemoglobin, hasil analisa akan terbaca dan di tunjukkan pada layar monitor.

\section{ANALISIS DATA}

Data yang diperoleh ditabulasi dan dihitung kemudian dianalisis menggunakan analisis ragam ANOVA sesuai Rancangan Bujur Sangkar Latin (RBSL) untuk mengetahui pengaruh perlakuan $\mathrm{p}>0,05$ sesuai petunjuk Steel and Torrie (1995).

\section{HASIL DAN PEMBAHASAN}

\section{FISIOLOGI DARAH}

Darah merupakan cairan yang bersirkulasi di dalam tubuh dan berperan penting untuk mempertahankan kondisi metabolisme tubuh agar tetap konstan. Darah berperan sebagai pembawa zat-zat nutrisi pakan yang dikonsumsi ke seluruh bagian tubuh dan membawa sisa metabolisme menuju ginjal dan kelenjar keringat (Murray et al., 2003). Rataan nilai metabolit darah sapi bali jantan penggemukan dengan berbagai perlakukan ditunjukkan pada Tabel 2.

Tabel 2. Pengaruh perlakuan terhadap profil metabolit darah

\begin{tabular}{lcccccccc}
\hline \multirow{2}{*}{ Parameter } & \multicolumn{9}{c}{ Perlakuan } & P-Value & Ket & $\begin{array}{c}\text { Kisaran } \\
\text { Normal }\end{array}$ \\
\cline { 2 - 8 } & \multicolumn{1}{c}{$\mathbf{P}_{\mathbf{1}}$} & $\mathbf{P}_{\mathbf{2}}$ & $\mathbf{P}_{\mathbf{3}}$ & $\mathbf{P}_{\mathbf{4}}$ & & & \\
\hline Urea Darah (mg/dl) & $34,92 \pm 0,5$ & $36,23 \pm 1,4$ & $32,06 \pm 1,6$ & $32,72 \pm 1,1$ & 3,12 & th & $26,6-56,7^{\mathrm{a}}$ \\
Glukosa Darah (mg/dl) & $57,72 \pm 2,4$ & $58,18 \pm 0,9$ & $54,64 \pm 1,5$ & $56,07 \pm 1,0$ & 1,09 & th & $43-100^{\mathrm{b}}$ \\
Hemoglobin (g/dl) & $12,49 \pm 0,9$ & $12,89 \pm 0,7$ & $12,83 \pm 0,7$ & $12,17 \pm 1,4$ & 6,41 & tn & $9,6-10,5^{\mathrm{c}}$ \\
\hline
\end{tabular}

Ket: ${ }^{\text {tn }}$ berpengaruh tidak nyata $(p>0,05),{ }^{a}$ Hungate (1966) ${ }^{\mathrm{b}}$ Mitruka et al. (1977) ${ }^{\mathrm{c}}$ Diparayoga et al. (2001)

\section{PENGARUH PERLAKUAN TERHADAP KONSENTRASI UREA DARAH}

Pada table 2 menunjukkan bahwa rataan konsentrasi urea darah pada perlakuan pakan $\mathrm{P}_{1}$ sebesar 34,92 $\pm 0,5 \quad(\mathrm{mg} / \mathrm{dl}), \quad \mathrm{P}_{2}$ sebesar $36,23 \pm 1,4 \quad(\mathrm{mg} / \mathrm{dl}), \quad \mathrm{P}_{3}$ sebesar $32,06 \pm 1,6$ $(\mathrm{mg} / \mathrm{dl}), \mathrm{P}_{4}$ sebesar $32,72 \pm 1,1(\mathrm{mg} / \mathrm{dl})$, Hasil yang diperoleh ini juga menggambarkan bahwa penggunaan protein pakan hasil integrasi rumput-legum-tanaman pangan oleh ternak sapi bali jantan cukup maksimal karena kadar urea darah yang dihasilkan masih berada pada kiran normal sesuai pendapat Hungate (1966) dikutip Tahuk et al. (2017) yang menyatakan bahwa kisaran kadar urea darah normal pada ternak sapi adalah 26,6-56,7 mg/dl (Tabel 2).

Berdasarkan hasil analisis statistik menunjukkan bahwa perlakuan pakan tidak berpengaruh nyata $(p>0,05)$ terhadap kadar urea darah ternak sapi bali jantan. Hal ini disebabkan karena konsumsi protein kasar pada masing-masing perlakuan yang juga tidak jauh berbeda dalam penelitian ini, dengan kata lain kandungan protein ransum perlakuan relative seragam, namun demikian tidak ditemukan variasi yang signifikan pada urea darah pada 
semua kempok perlakuan sapi bali jantan. Menurut Luan et al. (2020) urea darah dipengaruhi oleh pakan karena sebagian besar urea diperoleh dari penguraian protein yang berasal dari pakan. Pada ternak yang mempunyai asupan protein tinggi, sebagian besar protein tersebut akan mengalami fermentasi di rumen, sehingga berdampak peningkatan kadar urea dalam darah di atas dalam keadaan normal. Ditambahkan Munzaronah et al. (2010) bahwa keseragaman kandungan protein pakan yang dikonsumsi akan menghasilkan kadar urea darah yang tidak berbeda pula.

Hal ini juga menunjukkan bahwa pakan hasil integrasi yang diberikan pada ternak mampu dimanfaatkan oleh mikroba rumen dalam bentuk ammonia, serta metabolisme protein seimbang dengan jumlah energi yang tersedia sehingga hasil metabolisme protein dalam bentuk ammonia lebih banyak dimanfaatkan oleh mikrobia untuk mensintesis protein tubuhnya yang selanjutnya dicerna untuk kebutuhan berproduksi dibandinkan penyerapannya kedalam peredaran darah. Hasil yang diperoleh ini juga lebih tinggi dibandingkan hasil yang diperoleh Tahuk et al. (2017) pada penggemukan sapi bali jantan berbasis hijauan (Greenlot Fattening) di peternakan rakyat yaitu berkisar 23,65-24,81 $\mathrm{mg} / \mathrm{dl}$ dengan rataan $24,11 \mathrm{mg} / \mathrm{dl}$. Konsentrasi urea darah pada umumnya mencerminkan tingkat keseimbangan $\mathrm{N}$ di dalam rumen, sejauh dikaitkan dengan kebutuhan oleh mikroba rumen dan kebutuhan ternak inang, yaitu tingkat dimana jumlah dan komposisi dari asam amino memenuhi kebutuhan ternak inang (Tahuk et al., 2017).

\section{PENGaruh PERLAKUAN TERHADAP KONSENTRASI GLUKOSA DARAH}

Pada Tabel 2 menunjukkan bahwa rataan konsentrasi glukosa darah pada perlakuan pakan $\mathrm{P}_{1}$ sebesar 57,72 $\pm 2,4(\mathrm{mg} / \mathrm{dl}), \mathrm{P}_{2}$ sebesar $58,18 \pm 0,9 \quad(\mathrm{mg} / \mathrm{dl}), \quad \mathrm{P}_{3}$ sebesar $54,64 \pm 1,5$ $(\mathrm{mg} / \mathrm{dl}), \mathrm{P}_{4}$ sebesar 56,07 $\pm 1,0(\mathrm{mg} / \mathrm{dl})$, Hasil yang diperoleh ini juga menggambarkan bahwa penggunaan energi pakan hasil integrasi rumput-legum-tanaman pangan oleh ternak sapi bali jantan cukup optimal karena kadar glukosa darah yang dihasilkan masih berada pada kiran normal sesuai pendapat Menurut
Mitruka et al. (1977) kisaran normal kadar glukosa darah pada ternak sapi yang normal bervariasi antara 43-100 mg/dl (Tabel 2). Normalnya kadar glukosa darah ini selain karena faktor energi yang disuplai dari pakan yang dikonsumsi, juga karena adanya mekanisme kontrol oleh hormon insulin dan glukagon yang mengatur keseimbangan kandungan glukosa darah, dengan adanya sistem penjaga kadar glukosa darah melalui proses glikolisis, glikogenesis dan glukoneogenesis pada ternak ruminansia menyebabkan konsentrasi glukosa darah relatif konstan.

Berdasarkan hasil analisis statistik menunjukkan bahwa perlakuan berpengaruh tidak nyata $(p>0,05)$ terhadap kadar glukosa darah sapi bali jantan penggemukan. Hal ini menunjukkan bahwa pemberian pakan hasil integrasi tidak mempengaruhi kadar glukosa darah yang disebabkan karena pakan konsentrat menyediakan sumber energi komparabel pada semua kelompok perlakukan (Tabel 1), komparabel energy menyebabkan nilai glukosa pada semua kelompok perlakukan tidak berbeda nyata. Menurut Tahuk et al. (2017) nilai glukosa darah berhubungan erat dengan konsumsi energi, jika konsumsi energi rendah maka kadar glukosa darah juga rendah, sebaliknya konsumsi energi tinggi maka kadar glukosa darah juga tinggi (Parakkasi, 1999).

Hasil yang diperoleh ini juga tidak jauh berbeda jika dibandingkan hasil yang diperoleh Tahuk et al. (2017) pada penggemukan sapi bali jantan berbasis hijauan (Greenlot Fattening) di peternakan rakyat yaitu berkisar 56,94$61,19 \mathrm{mg} / \mathrm{dl}$ dengan rataan $58,60 \mathrm{mg} / \mathrm{dl}$. Hal ini disebabkan karena kedua percobaan ini samasama menggunakan pakan hijauaan, dalam penelitian ini pemberian pakan integrasi rumput unggul-legum dan tanaman pangan mampu menyediakan pati atau karbohidrat yang bersumber dari rumput unggul sehingga karbohidrat yang dikonsumsi ternak akan berfungsi sebagai sumber kerangka carbon, dan metabolisme energi. Menurut Astuti et al. (2011), pakan yang dikonsumsi telah mengalami hidrolisa karbohidrat dengan adanya enzim pemecah karbohidrat menjadi glukosa. lebih lanjut glukosa adalah nutrien yang sangat cepat untuk dijadikan sumber 
energi tubuh. Ditambahkan Tahuk et al. (2017) bahwa terdapat hubungan yang sangat erat antara suplai karbohidrat dan energi pada berbagai keadaan seperti fisiologis dan hematologis ternak untuk pertumbuhan.

\section{PENGARUH PERLAKUAN TERHADAP KADAR HEMOGLOBIN DARAH}

Tabel 2 menunjukkan bahwa rataan kadar hemoglobin darah pada perlakuan pakan $\mathrm{P}_{1}$ sebesar 12,49 $\pm 0,9(\mathrm{~g} / \mathrm{dl}), \mathrm{P}_{2}$ sebesar $12,89 \pm 0,7$ $(\mathrm{g} / \mathrm{dl}), \mathrm{P}_{3}$ sebesar 12,83 $\pm 0,7(\mathrm{~g} / \mathrm{dl}), \mathrm{P}_{4}$ sebesar $12,17 \pm 1,4(\mathrm{~g} / \mathrm{dl})$, Hasil yang diperoleh ini lebih tinggi dari kisaran normal hemoglobin darah sesuai pendapat Diparayoga et al. (2001) yang menyatakan bahwa kadar hemoglobin normal pada sapi bali yaitu 9,6 - 10,5 g/dl. Hal ini disebabkan karena pemanfatan pakan hasil integrasi oleh mikroba rumen cukup efisien terutama kandungan protein pakan untuk meningkatkan pertumbuhan ternak sehingga berdampak pada peningkatan hemoglobin dalam darah, Hemoglobin $(\mathrm{Hb})$ merupakan protein yang mempunyai daya gabung dengan oksigen dan membentuk oxyhemoglobin didalam sel darah merah, melalui fungsi ini oksigen dibawa dari paru-paru ke jaringanjaringan tubuh.

Hasil analisis statistik menunjukkan bahwa perlakuan berpengaruh tidak nyata $(\mathrm{P}>0,05)$ terhadap kadar hemoglobin darah ternak sapi bali jantan. Hal ini menunjukkan bahwa pemberian pakan hasil integrasi rumput unggullegum dan tanaman pangan tidak mempengaruhi kadar hemoglobin darah yang disebabkan karena pakan tersebut menyediakan sumber protein dan energi yang relatif seragam walaupun jenis dan spesies rumput berbeda. Menurut Raguati dan Rahmatang (2012) kadar hemoglobin dipengaruhi oleh kecukupan nutrisi, terutama protein dan energi sebagai penyusun hemoglobin, dan juga dipengaruhi oleh bangsa, umur, jenis kelamin dan aktivitas.

Kadar hemoglobin yang diperoleh lebih tinggi dari kisaran normal, namun hasil ini memberikan gambaran bahwa pakan hasil integrasi mampu menyediakan biomasa yang dibutuhkan mikroba rumen untuk meningkatkan aktivitasnya dalam metabolisme pakan. Menurut Astuti et al. (2011), hemoglobin sangat bermanfaat dalam mengikat oksigen dalam darah. Peningkatan kadar hemoglobin pada tubuh ternak dapat menyebabkan peningkatan efisiensi pertukaran oksigen dan karbondioksida, sedangkan jika terjadi penurunan kadar hemoglobin dapat menghambat metabolisme nutrisi dan sel.

Kadar urea, glukosa dan hemoglobin darah sapi bali jantan yang diberi pakan hasil integrasi rumput unggul masih dalam rentang nilai normal, yang juga ditandai dengan tidak adanya gejala keracunan nutrisi pada ternak sehingga pakan tersebut dapat menjadi pakan alternative bagi sapi bali jantan. Menurut Roland et al. (2014), ketidakseimbangan elektrolit serta nutrisi akan dapat menyebabkan terjadinya anemia hemolitik dan keracunan pakan.

\section{KESIMPULAN}

Disimpulkan bahwa perlakuan pakan tidak memberikan pengaruh antar perlakuan terhadap profil metabolit darah yang meliputi urea, glukosa dan hemoglobin darah sapi bali jantan penggemukan sehingga dapat dijadikan pakan alternative bagi sapi bali jantan.

\section{DAFTAR PUSTAKA}

Astuti DA, Baba AS and Wibawan IWT. 2011. Rumen fermentation, blood metabolites, and performance of sheep fed tropical browse plant. J Med. Pet. 34(3): 201-206.

Diparayoga IMG, Dwinata IM dan Dharmawan NS. 2014. Total Eritrosit, Hemoglobin, Pack Cell Volume, dan Indeks Eritrosit Sapi Bali yang Terinfeksi Cysticercus Bovis, Indonesia Medicus Veterinus, Fakultas Kedokteran Hewan, Universitas Udayana.

Gupta V, Rai PK and Risam KS. 2012. Integrated crop-livestock farming systems: a strategy for resource conservation and environmental sustainability. Indian Research Journal of Extension Education, Special Issue. 2:49-54.

Hungate RE. 1966. The rumen and its microbes. Academic Press, New York and London.

Kariyasa K. 2005. Sistem integrasi tanaman ternak dalam reorientasi kebijakan subsidi pupuk dan peningkatan pendapatan petani pusat penelitian dan pengembangan sosial ekonomi pertanian. J. Analisis Kebijakan Pertanian. 3(1): 68-80. 
Laboratorium Patologi Klinik. 2004. Penuntun Analisis Darah. Laboratorium Bio-Rep dan Kester. Fapet. Universitas Nusa Cendana.

Luan SE, Paulus KT dan Gerson FB. 2020. Profil Glukosa dan Urea Darah Sapi Bali Jantan yang digemukkan dengan Pakan Komplit yang Mengandung Level Protein Kasar berbeda. Journal of Animal Science. 1(4): 67-69

Mitruka BM, Rawnsley HM and Vadehra BV. 1977. Clinical Biochemical and hematological Reference Values in Normal Experimental Animals. Masson Publishing, Inc., New York.

Munzaronah, Soedarsono CMS, Lestari E, Purbowati dan Purnomoadi A. 2010. Parameter Darah Sapi Jawa Yang Diberikan Pakan Dengan Tingkat Protein Pakan Yang Berbeda. Dalam Prodising Seminar Nasional Teknologi Peternakan dan Veteriner. Pusat Penelitian dan Pengembangan Peternakan, Bogor. Hal.243-248.

Murray RK, Rodwell VW, Granner DK dan Mayes PA. 2003. Biokimia Harper. Ed 25. EGC. Jakarta.
Nurhidayati, Istirochah P, Anis S, Djuhari dan Basit A. 2008. Pertanian Organik Suatu Kajian Sistem Pertanian Terpadu dan Berkelanjutan. E-book Program Studi Agrotekhnologi, Fakultas Pertanian Universitas Islam Malang

Parakkasi A. 1999. Ilmu Nutrisi dan Makanan Ternak Ruminan. Universitas Indonesia Press, Jakarta.

Raguati dan Rahmatang. 2012. Suplementasi urea saka multinutrien blok (USMB) plus terhadap hemogram darah kambing peranakan ettawa (PE). Jurnal Peternakan Sriwijaya. 1(1): 55- 64.

Roland L, Drillich M and Iwersen M. 2014. Hematology as a diagnostic tool in bovine medicine. Journal of Veterinary Diagnostic Investigation. 26(5): 592-598

Steel RGD dan Torrie JH. 1995. Prinsip dan Prosedur Statistika. Edisi Kedua. Diterjemahkan oleh: B. Sumantri. PT. Gramedia Pustaka Utama, Jakarta.

Tahuk PK, Dethan AA dan Stefanus S. 2017. The blood glucose and urea profile of male Bali Cattle on greenlot fattening at smallholder farms. J Agripet. 17(2): 104111. 